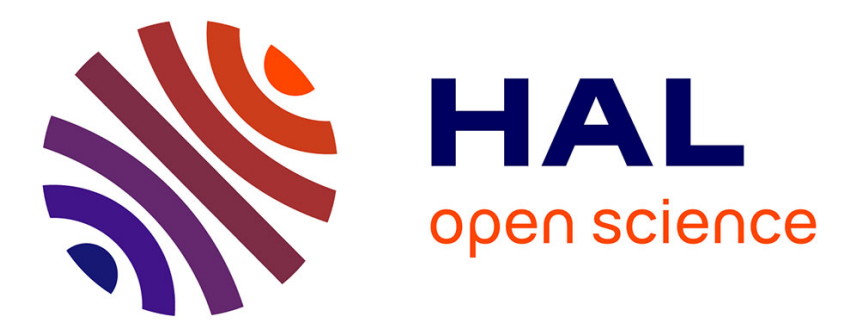

\title{
Selective cytotoxicity of arene tricarbonylchromium towards tumour cell lines
}

Jihene Elloumi-Mseddi, Sami Mnif, Nejmeddine Akacha, Bochra Hakim, Pascal Pigeon, Gérard Jaouen, Siden Top, Sami Aifa

\section{To cite this version:}

Jihene Elloumi-Mseddi, Sami Mnif, Nejmeddine Akacha, Bochra Hakim, Pascal Pigeon, et al.. Selective cytotoxicity of arene tricarbonylchromium towards tumour cell lines. Journal of Organometallic Chemistry, 2018, 862, pp.7-12. 10.1016/j.jorganchem.2018.01.036 . hal-01720644

\section{HAL Id: hal-01720644 https://hal.sorbonne-universite.fr/hal-01720644}

Submitted on 21 Mar 2018

HAL is a multi-disciplinary open access archive for the deposit and dissemination of scientific research documents, whether they are published or not. The documents may come from teaching and research institutions in France or abroad, or from public or private research centers.
L'archive ouverte pluridisciplinaire HAL, est destinée au dépôt et à la diffusion de documents scientifiques de niveau recherche, publiés ou non, émanant des établissements d'enseignement et de recherche français ou étrangers, des laboratoires publics ou privés. 


\title{
Selective cytotoxicity of arene tricarbonylchromium towards tumour cell lines
}

Jihene Elloumi-Mseddi ${ }^{a,}{ }^{,}$, Sami Mnif ${ }^{a}$, Nejmeddine Akacha $^{a}$, Bochra Hakim ${ }^{a}$, Pascal Pigeon $^{\text {b,c }}$, Gérard Jaouen ${ }^{\text {b,c }}$, Siden Top ${ }^{\text {, }}$, Sami Aifa ${ }^{a}$

${ }^{a}$ Laboratory of Molecular and Cellular Screening Processes, Centre of Biotechnology of Sfax Sidi Mansour Road Km 6, BP 1177, 3018 Sfax, Tunisia

${ }^{\mathrm{b}}$ Sorbonne Université, UPMC, CNRS, Institut Parisien de Chimie Moléculaire (IPCM), UMR 8232, 4, Place Jussieu, 75005 Paris, France

${ }^{\mathrm{c}}$ PSL, Chimie ParisTech, 11 Rue Pierre and Marie Curie, F-75005 Paris, France

${ }^{*}$ Corresponding author. Centre of Biotechnology of Sfax (University of Sfax), Sidi Mansour Road Km 6, BP 1177, 3018 Sfax, Tunisia. sami.aifa@cbs.rnrt.tn

\begin{abstract}
Metals are cytotoxic and could be harmful to human health; however, as their effects are dose dependent, some of them could be used in chemotherapy. In the present work, mineral chromium (VI) showed that it is cytotoxic on both tumour (MCF-7, HeLa, Hep2 and Caco-2) and non-tumour (HEK293) cell lines. Interestingly, among seven complexes of arene tricarbonylchromium, chromium (0) becomes more efficient in targeting tumour cell lines with less toxicity to non-tumour cells. Three of complexes (formyl benzene tricarbonylchromium 1, anisol tricarbonylchromium $\mathbf{2}$ and trimethoxybenzene tricarbonylchromium 3 ) show a decrease of $\mathrm{IC}_{50}$ values for all tested tumour cells compared to the non-tumour cells HEK293. The remaining compounds have an opposite effect; they are less toxic to tumour cells compared to HEK293. The present work demonstrates that some arene tricarbonylchromium are selectively active against cancer cells by inducing apoptosis. The role of formyl and methoxy groups in arene tricarbonylchromium is shown in complexes acquiring the selective tumour cytotoxicity.
\end{abstract}

Keywords: Organometallics; Cytotoxicity; Inorganic chromium (VI); Tricarbonylchromium; Tumour cell lines; $50 \%$ inhibitory concentration

\section{Introduction}


Metals are commonly considered as toxic to living organisms. Beryllium, cadmium, chromium, and nickel are among metals that are classified as carcinogenic.

Many chromium compounds were shown to induce tumours in animals and many epidemiologic studies showing risks of developing cancer were reported from workers exposure [1].

In particular, the tumour targets of chromium (VI) are essentially lung, nasal cavity and paranasal sinuses caused by inhalation. The major effects of chromium (VI) are mutations, genomic instability, aneuploidy, cell transformation [2], DNA cross-links reported in rat liver and Kidney [3], direct DNA damage in chick embryo hepatocytes [4] and other genetic effects [5]. Meanwhile the DNA damage related to chromium (VI) compounds depends on the reduction to reactive species by cellular redox components [6].

No evidence of carcinogenesis risk by the oral route of chromium (VI) and in drinking water; the international guidelines of WHO allow a maximum hexavalent chromium concentration at $0.05 \mathrm{mg} / \mathrm{L}$ [7] which corresponds to $1 \mu \mathrm{M}$.

Moreover, Levis and Majone (1979) studied the cytotoxicity of 11 hydrosoluble chromium compounds and showed that all of them inhibited non-tumour cell lines of hamster $[8]$.

By contrast to the toxicity effects, some metal ions are indispensable for vital reactions in living cells. In general, these metals are embedded in organic molecules such as cobalt in vitamin B6, iron in haemoglobin and $\mathrm{Mg}^{2+}, \mathrm{Zn}^{2+}, \mathrm{Mn}^{2+}$ playing the role of cofactors for many enzymes. It has been found that some metals are involved in chemical complexes that can be used as radiation protective agents [9] and as medicines such as Zn-diethylentriamine pentaacetate, approved by Food and Drug Administration (FDA), for the elimination of known or suspected internal contamination with the transuranic metals $(Z>92)$ plutonium, americium, and curium.

The success story of metal compounds in cancer therapy started with the discovery of cisplatin and its derivatives by Rosenberg. In fact, they were able to reduce solid and blood tumours in animals [10]. Cisplatin was approved by FDA since 1978 to treat testicular and ovarian cancer types and bladder cancer in 1993. Other derivatives have been developed and approved such as carboplatin since 1989 and oxaliplatin (for colorectal cancer) since 2002. New

platinum compounds are currently under consideration for the treatment of other cancer types like non-small lung cancer or prostate cancer. 
Interestingly, Chromium (VI) in $\mathrm{K}_{2} \mathrm{Cr}_{2} \mathrm{O}_{7}$ was found to induce apoptosis of a non-smallcell lung cancer cell line [11].

Between toxic effects and the benefits of metallic ions in life processes, the synthesis of organometallics was installed as a discipline combining metals and organic chemicals in order to produce new alternatives for bioactive molecules. This promising field of research is named "Bioorganometallic chemistry" [12].

Organometallic compounds have been extensively studied for their applications in medicine over the last two decades [13-18]. The first fruit was arsphenamine (Salvarsan), which is based on arsenic (despite its unfavourable reputation as poison) and azobenzene, serving for the treatment of syphilis and trypanosomiasis. This is how Dr. Ehrlich's Magic Bullet was born and initiating the concept of chemotherapy [19].

The complexes of Fe [20-23], Ru [24-26], Os [27,28] and Ag [29] have been found to be very active against cancer cells. Arene tricarbonylchromium group, for which the oxidation state of chromium is zero, has been attached to biological substances such as $\beta$-estradiol molecule to produce complexes that have been mainly studied for their capacity to act as a probe for the detection of biological substances by infrared spectroscopy [30]. One of the chromium complexes was recognized by androgen receptor [31]. It has been found that tricarbonylchromium compounds can release carbon monoxide for application in therapy. This type of compounds is known as CO-releasing molecules (CORMs) [32,33]. However, their use as antitumour agents has not been well developed. For this reason, we have examined some arene tricarbonylchromium complexes for their cytotoxic activity towards four tumour cell lines and one non-tumour cell line Hek293 (Human embryonic kidney cells 293) in order to select new potential anticancer drugs.

\section{Materials and methods}

\subsection{Cell lines and cultures}

Four cancer cell lines were used throughout this study: MCF-7 (Human Breast Adenocarcinoma), Caco-2 (Human Epithelial Colorectal Adenocarcinoma), HeLa (human cervical carcinoma cells), Hep2 known as a HeLa derivative cell line and Hek293 (Human embryonic kidney cells 293) as a non-tumour cell line. 
MCF-7, Caco-2, Hep2, HeLa and HEK293 cell lines were grown in DMEM supplemented with $10 \%$ foetal bovine serum, $50 \mathrm{IU} / \mathrm{ml}$ penicillin, $50 \mathrm{mg} / \mathrm{ml}$ streptomycin at $37{ }^{\circ} \mathrm{C}$ in a humidified $5 \% \mathrm{CO}_{2}$ atmosphere.

\subsection{Chemical compounds}

$\mathrm{K}_{2} \mathrm{Cr}_{2} \mathrm{O}_{7}$ is purchased from Sigma-Aldrich.

Compounds 1 [34], 2 [35], and 3 [36] were synthesized according to the literature procedures. The synthesis of Rac-1, 2-bis (hydroxyethyl)-benzenetricarbonylchromium 4 was published by Besançon et al. [37].

The synthesis of compounds 5 [38], 6 and 7 [39] has been published in literature.

Inorganic chromium $\mathrm{K}_{2} \mathrm{Cr}_{2} \mathrm{O}_{7}$ and organic chromium chemical compounds were solubilised in DMSO at the concentration of $165 \mathrm{mM}$. Just before treatment, each stock solution was diluted at the appropriate concentration.

\subsection{Proliferation assay}

Cells were grown in 96-well plates until $40 \%$ confluence. Then, the tested compound at the appropriate concentrations was added and incubated for $48 \mathrm{~h}$.

Cell viability was tested using the MTT assay against several cell lines as previously described by Mosmann [40]. This assay is based on the reduction of MTT into purple formazan crystals by the succinate dehydrogenase enzyme in the mitochondrial respiratory chain.

After treatment, the medium was removed and replaced with $100 \mu \mathrm{L}$ of fresh medium and $10 \mu \mathrm{L}$ of MTT solution ( $5 \mathrm{mg} / \mathrm{mL}$ in PBS). Four hours later, $100 \mu \mathrm{L}$ of $10 \%$ SDS solution were added to each well to dissolve the formazan. The optical density was evaluated at 570 $\mathrm{nm}$ using a Varioskan microplate reader (Thermofisher). The growth inhibition was expressed as follows: $(\%)$ cell survival $=(\mathrm{AT} / \mathrm{A} 0) \times 100$; where A0 is the control absorbance and AT the absorbance of the treated cells.

\subsection{Morphological changes}


Cells were plated in 24-well plates at $5 \times 104$ cells $/ \mathrm{mL}$ and grown for $24 \mathrm{~h}$. Furthermore, cells were incubated in the presence of chromium compound at $\mathrm{IC}_{50}$ concentration and incubated $48 \mathrm{~h}$.

Then, cells in culture were stained with methylene blue during $1 \mathrm{~h}$, viewed with phase contrast microscopy and photographed.

\subsection{DNA fragmentation analysis for detecting apoptosis}

All the cultured cell lines were treated separately by $\mathrm{IC}_{50}$ and lethal doses of each tested compound. After $24 \mathrm{~h}$, cells were harvested by centrifugation, washed by PBS1x and suspended in lysis buffer (20 mM EDTA - $100 \mathrm{mM}$ Tris-HCl pH 8.0, 1\% SDS) containing $100 \mu \mathrm{g} / \mathrm{mL}$ RNase and incubated overnight at $55^{\circ} \mathrm{C}$. Proteinase K $(100 \mu \mathrm{g} / \mathrm{mL})$ was added and incubated $2 \mathrm{~h}$ at $37{ }^{\circ} \mathrm{C}$. DNA was then precipitated with $2.5 \mathrm{vol}$ of absolute ethanol and finally dissolved

in Tris-EDTA pH8 after centrifugation. DNA samples were analyzed by electrophoresis on $1.5 \%$ agarose gel.

\subsection{Statistical analysis}

The data were summarized as the mean \pm SD of six independent experiments. Statistical comparisons for all experiments were performed using unpaired Student's test and the level of significance was set at $\mathrm{P} \leq 0.05$.

\section{Results}

\subsection{Chemical compounds}

Arene tricarbonylchromium compounds are organometallics produced by a complexation of arenes tricarbonylchromium group. 7 compounds were selected: formyl benzene tricarbonylchromium 1 [34], anisol tricarbonylchromium 2 [35], trimethoxybenzene tricarbonylchromium 3 [36] rac-1, 2-bis (hydroxyethyl)-benzenetricarbonylchromium 4 [37], $\mathrm{N}$-(1-phenylethyl)acetamido tricarbonylchromium 5 [38], and two bis-tricarbonylchromium respectively alcohol and ketone 6 and 7 [39]. The structure of the present compounds are summarized in Fig. 1. 
<smiles>CC([O])(Cl)C(=O)c1ccccc1C=O</smiles>

1<smiles>CC(=O)NC(c1ccccc1)c1ccccc1C(=O)O</smiles>

5<smiles>COc1ccccc1C(=O)C(=O)O</smiles>

2<smiles>COc1cc(OC)cc(C(=O)C(=O)[O-])c1</smiles>

3<smiles>CC(O)c1cccc(C(=O)C(=O)[O-])c1C(C)O</smiles>

4<smiles></smiles>

6<smiles>CC([O-])([O-])OC(=O)c1cccc(C(=O)c2ccc(N)c(C(=O)O)c2)c1</smiles>

7

Fig. 1 Arene tricarbonylchromium compounds.

\subsection{Anticancer activity}

Chromium chemicals including $\mathrm{K}_{2} \mathrm{Cr}_{2} \mathrm{O}_{7}$ were evaluated for their in vitro anticancer activities against human cancer cells using MTT assay. Four cancer cell lines have been chosen representing different malignant human tissues: breast adenocarcinoma, epithelial colorectal adenocarcinoma and cervical carcinoma. The Human embryonic kidney cells 293 were used in order to evaluate the toxicity against non tumour cells. All cell lines, Caco-2, HeLa, Hep2, MCF-7 and HEK293, were treated by increasing concentrations of each tested chemical. Fig. 2 shows the percentage of cell survival under increasing concentrations of the treatment. Untreated cells were used as controls.

The results showed clearly that the inhibition of cell growth was dose-dependent and increased while increasing the concentration of the used compound. The $\mathrm{IC}_{50}$ values are presented in Table 1 and Fig. 3. 

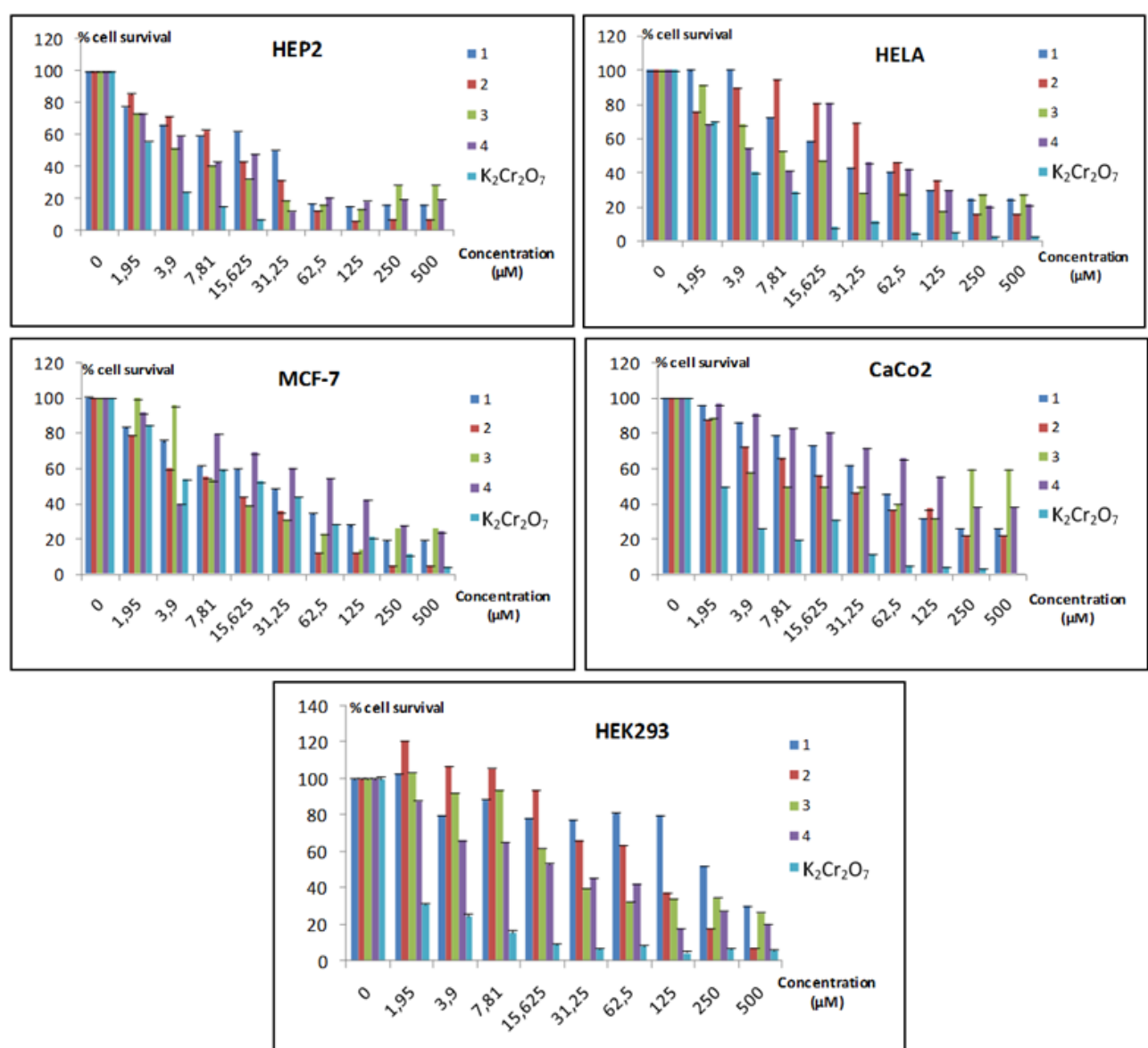

Fig. 2 Cytotoxic effect of the chromium compounds. Different concentrations of each compound were used to treat cells of Hep2, HeLa, MCF7, Caco-2 and HEK293.

Table 1 The $\mathrm{IC}_{50}$ values of the chromium compounds $(\mu \mathrm{M})$.

\begin{tabular}{|c|l|l|l|l|l|}
\hline Compound & \multicolumn{1}{|c|}{ Hela } & \multicolumn{1}{|c|}{ Caco-2 } & \multicolumn{1}{|c|}{ Hep-2 } & MCF-7 & \multicolumn{1}{|c|}{ Hek 293 } \\
\hline 1 & $14.89 \pm 0.6$ & $128.51 \pm 0.9$ & $56.61 \pm 2$ & $30.42 \pm 0.6$ & $325.92 \pm 25$ \\
\hline 2 & $55.33 \pm 9$ & $21.32 \pm 0.3$ & $17.36 \pm 0.9$ & $9.72 \pm 1$ & $101.04 \pm 13$ \\
\hline 3 & $14.87 \pm 1$ & $18.34 \pm 2$ & $5.79 \pm 0.2$ & $15.31 \pm 2$ & $25.21 \pm 2$ \\
\hline 4 & $3.60 \pm 0.5$ & $203.11 \pm 12$ & $8.62 \pm 0,6$ & $58.68 \pm 4$ & $7.87 \pm 0,9$ \\
\hline 5 & $118.29 \pm 9$ & $>100$ & $190 \pm 9$ & $491.8 \pm 20$ & $32.24 \pm 5$ \\
\hline 6 & $125.70 \pm 10$ & $>100$ & $262 \pm 13$ & $196.59 \pm 33$ & $96.32 \pm 12$ \\
\hline 7 & $59.24 \pm 6$ & $>100$ & $10.10 \pm 0.9$ & $61.56 \pm 2$ & $21.19 \pm 0.7$ \\
\hline $\mathrm{K}_{2} \mathrm{Cr}_{2} \mathrm{O}_{7}$ & $2.60 \pm 0.4$ & $2.40 \pm 0.2$ & $1.88 \pm 0.3$ & $20.93 \pm 0.6$ & $1.41 \pm 0.2$ \\
\hline
\end{tabular}




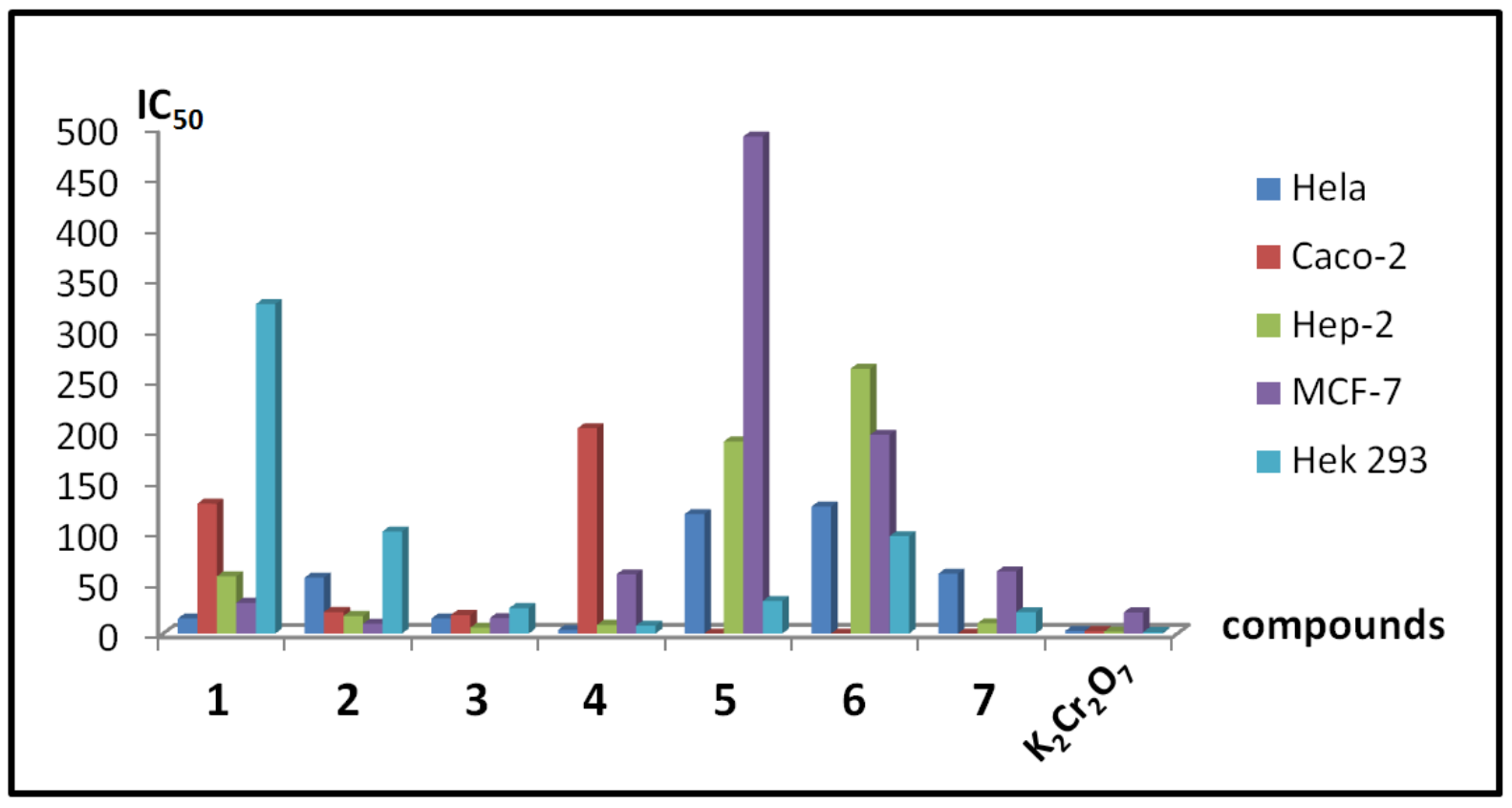

Fig. $3 \mathrm{IC}_{50}$ values and the specific tumour toxicity. Compounds $\mathbf{1}-\mathbf{3}$ are more active against tumour cell lines compared to the non tumour HEK93. Compounds 5-7 are showing a more active effect on $\mathrm{HEK} 293 . \mathrm{K}_{2} \mathrm{Cr}_{2} \mathrm{O}_{7}$ is a non-specific cytotoxic agent.

\subsection{Morphological changes}

When treated with the chromium molecules, the different cell lines presented morphological changes. These changes are followed in Hep2, HeLa, Caco-2 and MCF-7 treated with the $\mathrm{IC}_{50}$ of each compound. In fact, treated cells became rounded and pyknotic and many of them are detached from their substratum while untreated cells grew adherently on culture plates (Fig. 4). 

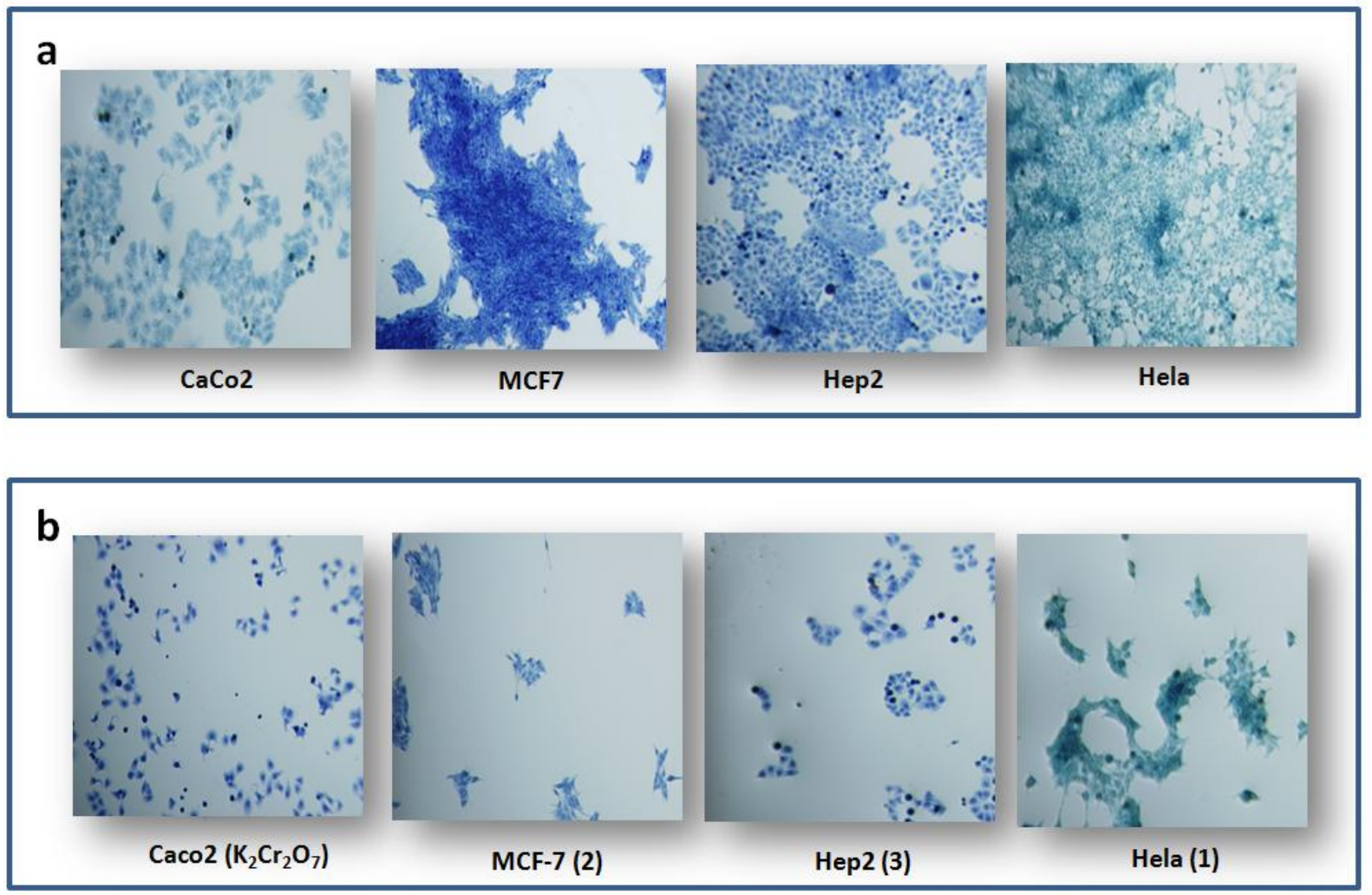

Fig. 4 Example of morphological changes caused by the chromium compounds on cultured cell lines. Treated cells are compared with these without treatment by microscopic observation. a: untreated cells. b: treated cells: $\mathrm{CaCo} 2\left(\mathrm{~K}_{2} \mathrm{Cr}_{2} \mathrm{O}_{7}\right)$ : $\mathrm{CaCo} 2$ cells treated with $\mathrm{K}_{2} \mathrm{Cr}_{2} \mathrm{O}_{7}$, MCF-7 (2): MCF-7 cells treated with compound 2, Hep2 (3): Hep2 treated with compound 3 and HeLa (1): HeLa cells treated with compound 1.

\subsection{DNA fragmentation analysis for detection of apoptosis}

Cells were treated with chromium compounds at $\mathrm{IC}_{50}$ and lethal concentrations before DNA extraction and analysis on agarose gel electrophoresis.

All tested compounds provoked DNA fragmentation when cells were treated at $\mathrm{IC}_{50}$ or lethal concentrations during 24 h. Fig. 5 shows an example of cell fragmentation. This result confirmed an apoptotic effect. 


\section{HeLa}

\section{Caco2}

\section{$\begin{array}{lllllllll}1 & N T & 1 L & 2 & 2 L & K & N T & K L & M\end{array}$}

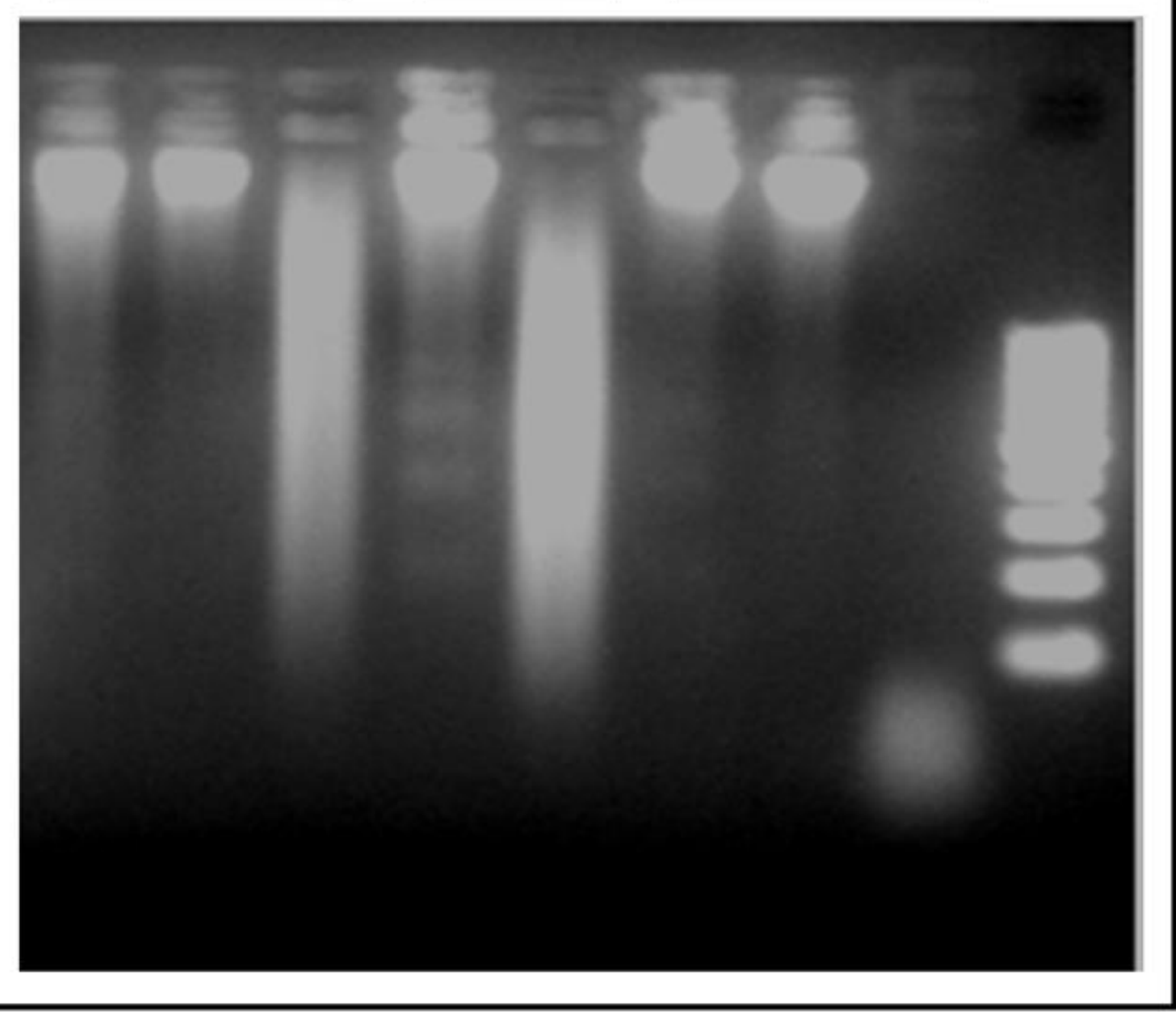

Fig. 5 Example of DNA fragmentation caused by chromium compounds. NT: the DNA of untreated cells, L: lethal dose; T1 and T2 correspond to the DNA of the treated cells by compounds 1 and 2; $\mathrm{k}$ : the DNA of the treated cells by $\mathrm{K}_{2} \mathrm{Cr}_{2} \mathrm{O}_{7} ; \mathrm{M}$ corresponds to the $100 \mathrm{pb}$

DNA ladder (thermo scientific). The cells are treated with the $\mathrm{IC}_{50}$ and the lethal concentrations of each compound before DNA extraction and analysis on agarose gel electrophoresis.

\section{Discussion}

The benefits of metals, particularly in human health or in human life activities, are hindered by their toxicity. Many applications of metals are avoiding the harmful doses but 
they are not all the time getting the needed efficiency like inorganic pesticides based on arsenic, copper sulfates, lead, mercury that are causing serious soil toxicity [41,42].

As expected, in the present work, the mineral chromium $\left(\mathrm{K}_{2} \mathrm{Cr}_{2} \mathrm{O}_{7}\right)$ is the most toxic compound to all tested cell lines with close $\mathrm{IC}_{50}$ values. Compared to the remaining compounds, the $\mathrm{IC}_{50}$ values of $\mathrm{K}_{2} \mathrm{Cr}_{2} \mathrm{O}_{7}$ were the lowest without any distinction between the non-tumour cell line and tumour cell lines (Table 1). Our results confirm the toxicity of mineral chromium (VI), already described, on non-tumour cells lines such as HBK and CHO of Hamster [8]. Moreover, the apoptotic effect of $\mathrm{K}_{2} \mathrm{Cr}_{2} \mathrm{O}_{7}$ was previously described in nonsmall-cell-lung cancer cell line [11]. We noticed a more pronounced toxicity on the nontumour cell line HEK293 showing the lowest $\mathrm{IC}_{50}$ value of $1.41 \mu \mathrm{M}$ that corresponds to 0.073 $\mathrm{mg} / \mathrm{L}$ which is slightly superior to $0.05 \mathrm{mg} / \mathrm{L}$ the allowed chromium contamination in water according to WHO [7].

Organometallic chemistry was developed to benefit from metals while decreasing their toxicity thanks to their incorporation in adequate organic molecules. In our work, this approach was confirmed: the synthesized organometallics harbouring chromium are displaying less toxicity to all the cell lines than $\mathrm{K}_{2} \mathrm{Cr}_{2} \mathrm{O}_{7}$ especially on the non-tumour cells (HEK293); we have obtained a wide range of proapoptotic toxicity depending on the tested compound and its dose. Interestingly, the toxicity of at least three arene tricarbonylchromium complexes (1, 2 and $\mathbf{3}$ ) was much more specific to tumour cell lines, which makes them good candidates as potential anti-cancer molecules. Moreover, we have obtained a selective toxicity of each tested compound against a specific cell line. In fact, compound $\mathbf{1}$ showed the lowest $\mathrm{IC}_{50}$ on HeLa $(14.89 \mu \mathrm{M})$ and on MCF-7 cells $(30.42 \mu \mathrm{M})$. Consequently, compound $\mathbf{1}$ is respectively 21 and 10-fold more active on HeLa and MCF-7 than HEK293 $\left(\mathrm{IC}_{50}=325 \mu \mathrm{M}\right)$. Compound 2 has a more pronounced toxicity on MCF-7 cells 10 times than HEK293 $\left(\right.$ IC $_{50}=$ 9.72 versus $101.04 \mu \mathrm{M}$ on HEK293). Compound 3 was more efficient against Hep-2 cells (more than 4 times compared to HEK293 with an $\mathrm{IC}_{50}=5.79$ versus $25.21 \mu \mathrm{M}$ ). Compound 4 was more toxic to HeLa cells also (more than 2 times compared to HEK293 with an $\mathrm{IC}_{50}=$ 3.60 versus $7.84 \mu \mathrm{M}$ ) and compound 7 was more toxic on Hep2 cells (more than 2 times compared to HEK293 with an $\mathrm{IC}_{50}=10.10$ versus $21.19 \mu \mathrm{M}$ ) (Fig. 3).

The comparison between the most efficient compounds revealed the importance of the aldehyde group in the arene tricarbonylchromium $\mathbf{1}$ which, among all the complexes, is showing the best specific toxicity on HeLa and MCF-7 compared to the non-tumour HEK293 cells. Meanwhile, compound $\mathbf{2}$ despite its low toxicity against HeLa, is the most toxic on the other cancer cell lines than all the remaining complexes giving rise to 4, 5 and 10 times 
toxicity respectively on Caco2, Hep2 and MCF-7 compared to HEK293 cells. It seems that the methoxy group reinforced the specific cytotoxicity of compound $\mathbf{2}$ but the presence of 3 methoxy groups on compound $\mathbf{3}$ was decreasing the toxicity against all cancer cell lines.

In the other hand, the methylcarbinol group of arene tricarbonylchromium $\mathbf{4}$ decreased the toxicity against tumour cells that became higher on HEK293 except on HeLa cells. The same conclusion is valid for compounds $\mathbf{5}$, containing the phenyl-CHNHCOCH3 , and $\mathbf{6}$, a bistricarbonylchromium containing $>\mathrm{CHOH}$ between the two arenes; both compounds lack the tumour specific toxicity. The dimeric arene tricarbonylchromium $\mathbf{7}$ differs from $\mathbf{6}$ just by substituting the $>\mathrm{CHOH}$ separating the two monomers by a $>\mathrm{C}=\mathrm{O}$ and $-\mathrm{NH}_{2}$ group on one arene; interestingly, 7 is acquiring a specific cytotoxicity against Hep2 cells.

To summarise, these results showed that compounds 1, 2 and $\mathbf{3}$ play a selective toxicity on tumour cell lines while 4, 5, 6 and $\mathbf{7}$ are, in general, more toxic to the non-tumour cell line. Moreover, based on these results, $\mathbf{1}$ could be selected as a potential candidate for the treatment of cervical and breast cancer represented by HeLa and MCF-7 cell lines and $\mathbf{2}$ could be a good candidate to treat breast cancer according to the results obtained with MCF-7 cell line. Finally, compounds $\mathbf{3}$ and $\mathbf{7}$ could be good candidates for cervical cancer represented by Hep2 cell line.

All compounds tested in the present work have arene tricarbonylchromium as a common structure but with different attached chemical groups.

\section{Conclusion}

We have selected 7 arene tricarbonylchromium compounds to study their antitumour activity against cancer cells (MCF-7, HeLa, Hep2 and Caco-2). By contrast to mineral chromium (VI), $\mathrm{K}_{2} \mathrm{Cr}_{2} \mathrm{O}_{7}$, which is cytotoxic to all cells including HEK293, arene tricarbonylchromium complexes, for which the oxidation state of chromium is zero, are less toxic. Their anti-tumour activity varies from one compound to another and also depends on the tumour cell types. Interestingly, three compounds, $\mathbf{1 ,} \mathbf{2}$ and $\mathbf{3}$, show the lowest $\mathrm{IC}_{50}$ values for all tested tumour cells compared to non-tumour cells HEK293. The nature of chemical groups attached to the arene moiety influences the specificity and the level of toxicity of each compound; our results highlight the role of formyl and methoxy groups in this selective antitumour activity. For example, due to the aldehyde group, compound $\mathbf{1}$ was 21 times more active on HeLa cells than HEK293 cells. The methoxy group allowed a wide range of tumour toxicity especially in compound $\mathbf{2}$. Chemical groups in compounds $\mathbf{5}, \mathbf{6}$ and $\mathbf{7}$ produced an 
opposite effect; they were less toxic to tumour cells. This work demonstrated that the cytotoxicity of certain arene tricarbonylchromium compounds can target selectively tumour cells depending on the attached chemical groups.

Therefore, in the future we intend to diversify the functional chemical groups attached to the arene tricarbonylchromium in order to generate a more interesting anti-cancer activity and select the best combinations that preserve normal cells intact and ultimately to understand the peculiar activity of this type of organometallics. In this context, the presence of a formyl and a methoxy groups in the same arene tricarbonylchromium could be very interesting in terms of tumour cytotoxicity.

\section{Conflicts of interest}

The authors declare no conflict of interest.

\section{Acknowledgements}

The authors wish to thank Dr. Dorra Driss for her valuable critical reading of the manuscript and Dr. Mamdouh Ben Ali who improved the captions of our figures.

This work was funded by the Tunisian Ministry of Higher Education and Scientific Research.

\section{References}

[1] IARC, IARC Monogr. Eval. Carcinog. Risks Hum. 49, 1990, 1-648.

[2] K. Straif, L. Benbrahim-Tallaa, R. Baan, Y. Grosse, B. Secretan, F. Fatiha Ghissassi, V. Bouvard, N. Guha, C. Freeman, L. Galichet, V. Cogliano, A review of human carcinogensPart C: metals, arsenic, dusts, and fibres, Lancet Oncol. 10 (5), 2009, 453-454.

[3] M.J. Tsapakos, T.H. Hampton and K.W. Jennette, The carcinogen chromate induces DNA cross-links in rat liver and kidney, J. Biol. Chem. 256 (8), 1981, 3623-3626.

[4] M.J. Tsapakos, T.H. Hampton, P.R. Sinclair, J.F. Sinclair, W.J. Bement, K.E. Wetterhahn, The carcinogen chromate causes DNA damage and inhibits drug-mediated induction of porphyrin accumulation and glucuronidation in chick embryo hepatocytes, Carcinogenesis 4 (8), 1983, 959-966. 
[5] V. Bianchi, R.D. Toso, P. Debetto, A.G. Levis, S. Luciani, F. Majone, G. Tamin, Mechanisms of chromium toxicity in mammalian cell cultures, Toxicology 17, 1980, 219224.

[6] K.E. Wetterhahn, J.W. Hamilton, J. Aiyar, K.M. Borges, R. Floyd, Mechanism of chromium(VI) carcinogenesis. Reactive intermediates and effect on gene expression, Biol. Trace Elem. Res. 21, 1989, 405-411.

[7] WHO, Chromium in Drinking-water. Background Document for Preparation of WHO Guidelines for Drinking-water Quality, 2003, World Health Organization; Geneva, (WHO/SDE/WSH/03.04/4).

[8] A.G. Levis, F. Majone, Cytotoxic and clastogenic effects of soluble chromium compounds on mammalian cell cultures, Br. J. Canc. 40 (4), 1979, 523-533.

[9] J.F. Weiss, M.R. Landauer, History and development of radiation-protective agents, Int. J. Radiat. Biol. 85 (7), 2009, 539-573.

[10] B. Rosenberg, L. VanCamp, The successful regression of large solid sarcoma 180 tumors by platinum compounds, Canc. Res. 30 (6), 1970, 1799-1802.

[11] S.M. Chuang, J.L. Yang, Comparison of roles of three mitogen-activated protein kinases induced by chromium (VI) and cadmium in non-small-cell lung carcinoma cells, Mol. Cell. Biochem. 222, 2001, 85-95.

[12] S. Top, G. Jaouen, A. Vessières, J.P. Abjean, D. Davoust, C.A. Rodger, B.G. Sayer, M.J. McGlinchey, Chromium tricarbonyl complexes of estradiolderivatives: differentiation of alpha- and beta-diastereomers using 1- and 2-dimensional NMR spectroscopy at $500 \mathrm{MHz}$, Organometallics 4, 1985, 2143-2150.

[13] G. Jaouen, M. Salmain, Bioorganometallic Chemistry Applications in Drug Discovery, Biocatalysis, and Imaging, 2015, Wiley-VCH; Weinheim, Germany.

[14] G. Jaouen, S. Top, Advances in organometallic chemistry and catalysis, In: A.J.L. Pombeiro, (Ed), 2013, John Wiley, Hoboken; New Jersey, 563-580.

[15] K. Kowalski, Ferrocenyl-nucleobase complexes: synthesis, chemistry and applications, Coord. Chem. Rev. 317, 2016, 132-156.

[16] M. Dôrr, E. Meggers, Metal complexes as structural templates for targeting proteins, Curr. Opin. Chem. Biol. 19, 2014, 76-81.

[17] C.G. Hartinger, N. Metzler-Nolte, P.J. Dyson, Challenges and opportunities in the development of organometallic anticancer drugs, Organometallics 31, 2012, 5677-5685.

[18] P. Zhang, P.J. Sadler, Advances in the design of organometallic anticancer complexes, J. Organomet. Chem. 839, 2017, 5-14. 
[19] S. Gibaud, G. Jaouen, Arsenic - based drugs: from Fowler's solution to modern anticancer chemotherapy, Top. Organomet. Chem. 32, 2010, 1-20.

[20] G. Jaouen, A. Vessières and S. Top, Ferrocifen type anti-cancer drugs, Chem. Soc. Rev. 44, 2015, 8802-8817.

[21] Y. Wang, M.A. Richard, S. Top, P.M. Dansette, P. Pigeon, A. Vessières, D. Mansuy, G. Jaouen, Ferrocenyl quinone methide-thiol adducts as new antiproliferative agents: synthesis, metabolic formation from ferrociphenols, and oxidative transformation, Angew. Chem. Int. Ed. 55, 2016, 10431.

[22] Y. Wang, P. Pigeon, S. Top, M.J. McGlinchey, G. Jaouen, Organometallic antitumor compounds: ferrocifens as precursors to quinone methides, Angew. Chem. Int. Ed. 54, 2015, 10230.

[23] J.d.J. Cazares-Marinero, O. Buriez, E. Labbé, S. Top, C. Amatore, G. Jaouen, Synthesis, characterization, and antiproliferative activities of novel ferrocenophanic suberamides against human triple-negative MDA-MB-231 and hormone-dependent MCF-7 breast cancer cells, Organometallics 32, 2013, 5926.

[24] E. Păunescu, S. McArthur, M. Soudani, R. Scopelliti, P.J. Dyson, Nonsteroidal antiinflammatory organometallic anticancer compounds, Inorg. Chem. 55, 2016, 1788-1808.

[25] N.P.E. Barry, P.J. Sadler, Exploration of the medical periodic table: towards new targets, Chem. Commun. 49, 2013, 5106.

[26] J.J. Soldevila-Barreda, I. Romero-Canelýn, A. Habtemariam, P.J. Sadler, Transfer hydrogenation catalysis in cells as a new approach to anticancer drug design, Nat. Commun. 6, 2015, 6582 .

[27] M. Hanif, M.V. Babak, C.G. Hartinger, Development of anticancer agents: wizardry with osmium, Drug Discov. Today 19, 2014, 1640.

[28] H.Z.S. Lee, O. Buriez, F. Chau, E. Labbé, R. Ganguly, C. Amatore, G. Jaouen, A. Vessières, W.K. Leong, S. Top, Synthesis, characterization, and biological properties of osmium-based tamoxifen derivatives - comparison with their homologues in the iron and ruthenium series, Eur. J. Inorg. Chem. 25, 2015, 4217-4226.

[29] B. Bertrand, A. Casini, A golden future in medicinal inorganic chemistry: the promise of anticancer gold organometallic compounds, Dalton Trans. 43, 2014, 4209-4219.

[30] M. Salmain, A. Vessières, P. Brossier, I.S. Butler, G. Jaouen, Carbonylmetalloimmusay (CMIA) a newtype of non-isotopic immunoassay. Principles and applications to phenobarbital assay, J. Immunol. Methods 148, 1992, 65-75. 
[31] S. Top, C. Thibaudeau, A. Vessières, E. Brulé, F.L. Bideau, J.M. Joerger, M.A. Plamont, S. Samreth, A. Edgar, J. Marrot, P. Herson, G. Jaouen, Synthesis and structure activity relationship of organometallic steroidal androgen derivatives, Organometallics 28, 2009, $1414-1424$.

[32] C.C. Romao, H.L.A. Vieira, Metal carbonyl prodrugs: CO delivery and beyond, In: G. Jaouen and M. Salmain, (Eds.), Bioorganometallic Chemistry: Applications in Drug Discovery Biocatalysis, and Imaging, 2014, WileyVCH Verlag GmbH \& Co. KGaA; Weinheim, Germany.

[33] C. Nagel, S. McLean, R.K. Poole, H. Braunschweig, T. Kramera, U. Schatzschneider, Introducing $\left[\mathrm{Mn}(\mathrm{CO})_{3}(\text { tpa- } \kappa 3 \mathrm{~N})\right]^{+}$as a novel photoactivatable CO-releasing molecule with well-defined iCORM intermediates-synthesis, spectroscopy, and antibacterial activity, Dalton Trans. 43, 2014, 9986-9997.

[34] R. Schreiner, A.B. Ellis, Adduct-mediated photochemistry. Evidence for excited-state reordering in (acetophenone)tricarbonylchromium(O) upon adduct formation with tris(6,6,7,7,8,8,8-heptafluoro-2,2-dimethyl-3,5-octanedionato)europium(III), J. Am. Chem. Soc. 104, 1982, 3374.

[35] C.A.L. Mahaffy, P.L. Pauson, ( $\eta^{6}$-Arene)Tricarbonylchromium complexes, Inorg. Synth. 19, 1979, 154.

[36] J.P. Djukic, F. Rose-Munch, E. Rose, F. Simon, Nucleophilic aromatic substitutions: hydrodealkoxylation, hydrodehalogenation and hydrodeamination of alkoxy, halogeno, and amino $\left(\eta^{6}\right.$ - Arene)tricarbonylchromium complexes, Organometallics 14, 1995, 2027-2038.

[37] J. Besançon, S. Top, J. Tirouflet, B. Gautheron, Y. Dusausoy, Pseudoasymétrie dans la série du benchrotrene I. Synthese des trois glycols ortho-substitues $(\mathrm{OC})_{3} \mathrm{CrC}_{6} \mathrm{H}_{4}\left(\mathrm{CHOHCH}_{3}\right)_{2}$, J. Organomet. Chem. Soc. 94, 1975, 35-46.

[38] S. Top, G. Jaouen, N-alkylation of nitriles using chromium tricarbonyl complexes of benzyl alcohol and its derivatives: new perspectives for the Ritter reaction, J. Org. Chem. 46, 1981, 78-82.

[39] S. Top, G. Jaouen, Synthèse directe de composés aréniques bis-chrome tricarbonyles, J. Organomet. Chem. 182, 1979, 381-392.

[40] T. Mosmann, Rapid colorimetric assay for cellular growth and survival: application to proliferation and cytotoxicity assays, J. Immunol. Meth. 65, 1983, 55-63.

[41] M. Vahter, Methylation of inorganic arsenic in different mammalian species and population groups, Sci. Prog. 82, 1999, 69-88. 
[42] E. Gimeno-García, V. Andreu, R. Boluda, Heavy metals incidence in the application of inorganic fertilizers and pesticides to rice farming soils, Environ. Pollut. 92 (1), 1996, 19-25. 